\title{
Cezary Zalewski Sztolnie mitów. Mitologiczne dyskursy Mieczysława Jastruna i Zbigniewa Herberta
}

ABSTRACT. Zalewski Cezary, Sztolnie mitów. Mitologiczne dyskursy Mieczysława Jastruna $i$ Zbigniewa Herberta [Drifts of myths. Mythological discourses of Mieczysław Jastrun and Zbigniew Herbert]. „Przestrzenie Teorii” 15. Poznań 2011, Adam Mickiewicz University Press, pp. 175-184. ISBN 978-83-232-2293-4. ISSN 1644-6763.

This article deals with M. Jastrun's and Z. Herbert's essays in which mythological figures (Minotaur, Iphigenia) appear. Demythologisation strategies of both authors are presented, which consist in either direct or indirect (most often ironic) questioning of sacrificial rites. Mythological murders are deprived of their primary, ritual justification, becoming an expression of unjustified and collective aggression.

Twórczość Mieczysława Jastruna oraz Zbigniewa Herberta należy niewątpliwie do różnych poetyk, które artykułują odmienne doświadczenia $\mathrm{w}$ zakresie tak pokoleniowym, jak i biograficznym. Zestawianie ich utworów domaga się zatem uzasadnienia, zwłaszcza że reprezentują one także inne gatunki czy praktyki dyskursywne. Niemniej, obaj pisarze podejmują ten sam - mitologiczny - temat, który ze względu na uniwersalny charakter sprzyja rozmaitym i kolejnym eksploracjom. O wiele ważniejszy jest więc fakt, iż u obu autorów analogiczne pozostają okoliczności zewnętrzne oraz perspektywa ujęcia pewnych kwestii. Zarówno u Jastruna, jak i u Herberta zainteresowanie tradycją mitologiczną wynika z edukacji i własnych pasji, które zostają uzupełnione obowiązkowymi podróżami, jakie obaj pisarze odbyli do Grecji. Wspólny jest im również ambiwalentny stosunek do mitologicznych przekazów, niezależnie od tego, czy ów dualizm jest wyrażany pośrednio czy bezpośrednio. $\mathrm{Z}$ jednej bowiem strony autorzy ci mają wyróżniony - chociaż raczej odrębny - zestaw fascynujących zagadnień, które dogłębnie i wielostronnie analizują, dlatego nie pomijają także ich różnorodnych (np. filozoficznych, artystycznych) funkcjonalizacji. Z drugiej jednak strony dostrzegają oni $\mathrm{w}$ mitologii elementy przerażające, wywołujące awersję czy nieskrywany sprzeciw. Można by nawet zaryzykować hipotezę, wedle której ów pierwszy krąg problemów jest peryferyjny, gdyż został już rozpoznany, kulturowo zinternalizowany; natomiast drugi - tkwi w centrum, które wciąż jest nieprzeniknione, oporne względem prób eksplikacji. Pisarze zresztą 
nie tylko sami zmagają się z tą kwestią, ale także stawiają czytelnikom wyzwanie, najtrafniej zdefiniowane przez Herberta:

przez opuszczone sztolnie mitów i religii dotrzecie do nagich bogów bez symboli umarłych to jest wiecznych w cieniu swych potworów ${ }^{1}$.

To, co w micie najbardziej intrygujące, ale zarazem tajemnicze, ma charakter monstrualny, nieludzki. Dzieje się tak dlatego, iż wszelkie deformacje prowadzą do aktów okrucieństwa i zbrodni wymykających się analizie. Celem niniejszego artykułu jest porównanie utworów, w których i Jastrun, i Herbert, sięgając po te same „przykłady”, starają się wyjaśnić mechanizmy mitologicznej przemocy.

\section{Głowa Minotaura}

Jastrun, przedstawiając w Micie śródziemnomorskim losy Minotaura, dokonuje znaczącej selekcji. Usuwa bowiem moment kulminacyjny i koncentruje się na wydarzeniach początkowych oraz końcowych, które dotyczą już innego bohatera - Dedala. Uzasadnienie tego zabiegu zostaje zasugerowane przez radykalną zmianę perspektywy, dzięki czemu relacja odzwierciedla punkt widzenia Kreteńczyków, poddanych króla Minosa. Od nich narrator uzyskuje informacje, wedle których:

Minotaur jest dzieckiem potwornej miłości. Półludzki stwór mieszka w labiryncie i żąda ofiar ludzkich. Nie chce żreć mięsa zwierzęcego ani trawy. Łagodny król Minos nie może znieść jego przejmującego krzyku. Minotaur jest zawsze głodny. W końcu król postanawia rzecz skierować na tory polityki międzynarodowej. Żąda od Ateńczyków corocznego haraczu: siedmiu chłopców i siedmiu dziewcząt, pastwy dla Minotaura (M, 23) $)^{2}$.

Ofiara natychmiast przynosi niezawodny skutek:

odtąd milkną ryki Minotaura. Król Minos nie cierpi już na nieznośny ból głowy, sypia po nocach i cieszy się, że krwawa danina nie obciążyła obywateli jego państwa $(\mathrm{M}, 23)$.

Ten pastisz „czytanek mitologicznych” (por. M, 22) potrzebny jest pisarzowi w celu odtworzenia pierwotnej postawy. Składa się na nią przekonanie, zgodnie z którym cykliczne uśmiercanie ludzi jest niezbędnym i koniecznym warunkiem bezpiecznej egzystencji zarówno wewnątrz danej

1 Z. Herbert, Podróż, [w:] Elegia na odejście, Wrocław 1995, s. 24.

M. Jastrun, Mit śródziemnomorski, Warszawa 1962. Dalsze cytaty z tego tomu opatruję skrótem M, cyfra w nawiasie oznacza numer strony. 
grupy, jak też pomiędzy wspólnotami. Założenie takie nie jest ani kwestionowane, ani - tym bardziej - eksplikowane; pewną wskazówkę mógłby stanowić jedynie fakt, iż ofiary nie należą do społeczności, która je składa. Oznacza to, że ofiarniczy proceder wymaga odpowiedniej selekcji, której brak zapewne uczyniłby go niefunkcjonalnym, prawdopodobnie prowadząc do przeciwnego efektu w postaci zemsty czy serii odwetów. Ofiara musi być obca, tak aby nikt nie sprzeciwiał się jej zabiciu.

Mitologiczny pastisz Jastruna pomija finał losu Minotaura, sugerując, iż Kreteńczycy nie są tą sprawą zainteresowani. Nie jest zatem wykluczone, że uśmiercenie potwora oznaczałoby dla nich - tyleż niebezpieczną, ile niewiarygodną - próbę zniesienia ofiarniczych praktyk. Dopiero taka presupozycja wyjaśnia, dlaczego pisarz podkreśla późniejszy brak zasadniczych zmian w tej kwestii. Usunięcie Minotaura wytworzyło bowiem pustkę $\mathrm{w}$ labiryntowym pałacu, która natychmiast została uzupełniona osobą jego architekta. Identyczna sytuacja obu tych postaci jest uderzająca:

Król Minos, pragnąc mieć wielkiego inżyniera i artystę tylko na własny użytek, nie pozwala mu na wyjazd do innych krajów (prawdopodobnie na Sycylię) i zamyka go wraz z ukochanym synem Ikarem w ogromnym pałacu, w którym nie ma już Minotaura. Dedalos odczuwa podwójnie to zamknięcie, widzi w nim zapewne aluzję do zabójstwa Talosa, chęć poniżenia go przez zrównanie z potworem, którego miejsce ma zająć (M, 34-35).

Zestawienie jest interesujące, chociaż Jastrun nie wyprowadza $\mathrm{z}$ niego żadnych wniosków. A przecież ta paralela pokazuje, po pierwsze, że mitologiczne monstrum zawsze niweluje granicę między człowiekiem a zwierzęciem (uciekający Dedal przypomina ptaka) oraz, po drugie, iż nieprzerwana obecność takiego czy innego potwora wymaga również niszczenia kolejnych istot (upadek Ikara zawiera sens ofiarniczy). Rekonstruując mitologię, pisarz przeczuwa więc, że zawiera ona apologię nieprzerwanej, nieustającej ofiary, dzięki której wspólnota zyskuje stabilizację.

Herbert doskonale zdaje sobie sprawę, że taka wizja jest już częścią kultury, która - przynajmniej na pewnym etapie - nie istnieje bez mitologii. Zatem przeprowadzając własne dociekania, pomija on ten wtórny przekaz i koncentruje się na samej „historii”, czyli na tym, co wydarzyło się naprawdę. Dlatego narrator Historii Minotaura nie tylko nie utożsamia się z tymi, wśród których ów mit funkcjonuje, ale kierowany empatią opowiada się po stronie bohatera ${ }^{3}$.

${ }^{3}$ Zamysł ten został przez Herberta explicite potwierdzony już wcześniej. W Labiryncie nad morzem poeta stwierdził bowiem: „Biedny Minotaur! Miałem dla niego, od zamierzchłego dzieciństwa, więcej czułości niż dla Tezeusza, Dedala czy innych spryciarzy. Kiedy 
W Historii Minotaura Herbert przede wszystkim dokonuje demityzacji potwora. Bohater nie jest bowiem monstrualnym połączeniem człowieka i byka, ale ludzkim dzieckiem, którego odmienność polegała jedynie na zbyt dużej głowie. Ta skaza somatyczna uzyskuje zresztą dopełnienie mentalne, ponieważ książę Minotaur, nie mając sprawnego umysłu, jest opanowany przez doznania afektywne (np. melancholię).

Jeśli więc tego rodzaju wada staje się powodem tragedii, to nie jest wykluczone, iż owe powody są tylko pretekstami. Herbert nie stawia tej kwestii wyraźnie, ponieważ koncentruje się na prezentacji fabuły. Składa się ona $z$ trzech etapów, w których powtarza się gest odrzucenia. Najpierw wypierają się księcia kapłani, dlatego zostaje on odizolowany w specjalnie zbudowanym labiryncie. W nim jednak zamiast pomocy spotyka Minotaura niechęć ze strony „pedagogów”, którzy nie są go w stanie niczego nauczyć. Ostatecznie zatem wypiera się go sam ojciec, zlecając Tezeuszowi morderstwo.

Finał tragedii jest następujący:

Przez labirynt - niepotrzebny już elementarz - wraca Tezeusz niosąc wielką, krwawą głowę Minotaura o wytrzeszczonych oczach, w których po raz pierwszy kiełkować zaczęła mądrość - jaką zwykło zsyłać doświadczenie $(\mathrm{K}, 90)^{4}$.

Herbert demaskuje tu sposób postępowania względem bohatera. Jeśli bowiem, po pierwsze, rozpoczął się u niego proces przyswajania informacji, oznacza to, iż nie był zupełnie do tego niezdolny. Nie jest więc wykluczone, że podkreślana uprzednio ignorancja była albo przesadzona, albo wynikała ze zbyt wysokich wymagań (oraz braku odpowiedniego podejścia). Obie możliwości wzmacniają przypuszczenie o pretekstowym charakterze zarzutów względem Minotaura.

Po drugie - abstrakcyjna, oderwana wiedza była jedyną, do jakiej książę mógłby mieć dostęp. Gdyby bowiem proces edukacji rozpoczął się od doświadczenia, jego wyniki zapewne okazałyby się zbyt drastyczne. To, o czym umierający Minotaur zdążył się przekonać, dotyczy przecież fundamentalnego związku między mądrością a przemocą. Polega on na takim posługiwaniu się siłą, które będzie precyzyjne oraz skuteczne: zagwarantuje śmierć temu, komu została ona przeznaczona - i nikomu więcej. Jeśli tak, to rozpoznanie własnej roli ofiary pojawia się u Minotaura tyle nieoczekiwanie, ile, istotnie, zbyt późno.

pierwszy raz ojciec opowiadał mi tę bajkę, uczułem bolesny skurcz serca i współczucie dla pół zwierza, pół człowieka, spętanego labiryntem i obcą sobie ludzką historią, pełną podstępów i toporów" (Z. Herbert, Labirynt nad morzem, Warszawa 2000, s. 42).

${ }^{4}$ Z. Herbert, Historia Minotaura, [w:] tegoż, Król mrówek, Warszawa 2001, s. 90.

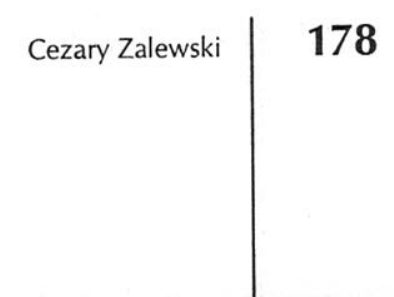




\section{Cień Ifigenii}

Wydaje się, iż kwestia mitycznych zbrodni stale intrygowała Jastruna, gdyż zapisując wrażenia z podróży do Grecji, nieustannie powraca do wydarzeń związanych z Ifigenią. Pisarz wyraźnie podkreśla, iż w tym właśnie przypadku temporalny i emocjonalny dystans zostaje zawieszony: o ile bowiem inne, równie tragiczne postacie są dla niego raczej obojętne, o tyle los tej jednej obsesyjnie niepokoi i zmusza do refleksji. Podsumowując swoją wizytę, Jastrun stwierdza zatem:

Pozostał cień Ifigenii, która pierwsza stała się ofiarą podłego egoizmu i piekielnej pychy Agamemnona. Mam ten cień przed oczami $(\mathrm{P}, 112)^{5}$.

Ten fragment mitu pozwala pisarzowi na rozpoznanie dwóch kwestii. Pierwsza dotyczy istoty najstarszych obrzędów, które zakładały:

zaufanie do znaków, mitycznych symboli, wreszcie do krwi, która ma przebłagać bóstwa! Krew ta w wiekach zamierzchłych była krwią ludzi złożonych na ofiarę. Rzadko się zdarzało (i to w późniejszych czasach), by zwierzę nagle znalezione przy ołtarzu ofiarnym zastąpiło człowieka, jak w jednej wersji mitu Ifigenię (P, 29).

Zatem pierwotne, podstawowe i - jak dopowiada Jastrun (por. P, 57) - najbardziej uniwersalne formy religijności wymagają ludzkiej krwi. Znamienny pozostaje jednak fakt, iż obserwacje te nie prowadzą do dalszych dociekań nad strukturą czy funkcją prymitywnego sacrum. Rezygnując $\mathrm{z}$ transcendentalnych refleksji, autor koncentruje się wyłącznie na perspektywie antropologicznej. Przypadek Ifigenii prowadzi bowiem do wniosku, zgodnie z którym:

Baśnie skandynawskie, germańskie, mity greckie - są to niewyczerpane źródła dla badacza różnych form okrucieństwa, masochizmu i sadyzmu, które (te schorzenia) idą często obok siebie [...].

Mitologia grecka zdradza ze szczególną wyrazistością, przy całym swoim bogactwie artystycznym, przy niezwykłej wyobraźni, schorzenia, które przybierają różne formy mniej lub bardziej okrutnego myślenia i działania. Są to rzeczy powszechnie znane, ale jednak mimo wszystko nie dość silnie podkreślane, a przecież w tych rozlicznych obrazach męki i nędzy ludzkiej objawia się jakaś bynajmniej niemała część natury homo sapiens (P, 109).

Formy mitologicznej przemocy są dla pisarza skandalem, przeciwko któremu ostro protestuje, ale którego nie potrafi wytłumaczyć. Jeśli bowiem człowiek pozostaje za nie odpowiedzialny, oznacza to, iż aktywność

${ }^{5}$ M. Jastrun, Podróż do Grecji, Warszawa 1978. Dalsze cytaty z tego tomu opatruję skrótem $\mathrm{P}$, cyfra w nawiasie oznacza numer strony. 
leżąca u podstaw tych przekazów albo jest anormalna (wręcz dewiacyjna), albo przynależy do samej istoty tego, co ludzkie. Te propozycje są wyraźnie alternatywne i prowadziłyby eksplikację w zupełnie odmiennych kierunkach, ale Jastrun poprzestaje na ich skonstatowaniu, kultywując własne zgorszenie mitologicznym barbarzyństwem ${ }^{6}$.

$\mathrm{O}$ wiele bardziej dociekliwy okaże się natomiast $\mathrm{w}$ drugiej kwestii powstałej z rozważań nad tragedią Ifigenii. Pisarz zestawia bowiem pierwotną oraz późniejszą wersję mitu i zauważa radykalną zmianę dotyczącą rodzaju ofiary. Obserwacja ta zawiera dwie intuicje: wedle pierwszej najbardziej drastyczna scena mitu - poświęcenie Ifigenii - powinna zostać albo usunięta, albo odpowiednio zneutralizowana; wedle drugiej natomiast właściwym środkiem dla osiągnięcia tego celu jest zastąpienie ofiary ludzkiej - zwierzęcą.

Obu tych refleksji Jastrun nie traktuje analogicznie. Druga sprowadza się jedynie do twierdzenia o niewiarygodnym i nieprawdopodobnym dodatku, jaki został sprokurowany na zasadzie deus ex machina, sprawiając, iż mityczny przekaz jest tu niespójny, sprzeczny (por. P, 106-107, 108; M, 93). Założenie takie wyklucza więc tezę, zgodnie z którą powyższa substytucja dokładnie odzwierciedla ewolucję rytuału polegającą na rezygnacji $\mathrm{z}$ ofiar ludzkich.

Intrygujące pozostaje tylko spostrzeżenie dotyczące cenzury modyfikującej mit. Jej motywacje nurtowały Jastruna już w Micie śródziemnomorskim, gdzie stwierdzał:

Jestem przekonany, iż owo happy end dorabiane było do pramitów z premedytacją i że można $\mathrm{z}$ tego faktu wyciągnąć pewne wnioski. Jest ono wyrazem istniejącego w naturze ludzkiej popędu do maskowania i ukrywania prawdy. Zbyt bolesne sprawy człowiek odpycha różnymi sposobami; jednym z nich jest właściwość pamięci, która zapomina o przykrych zdarzeniach. W ten sposób zapomnienie staje się częścią istnienia, nie tylko pamiętanie, tak jak nicość, spowijająca wszelki byt, gwarantuje jego obecność. Optymistyczne zakończenie tragedii jest wyrazem kompromisu, który trzeba znaleźć za wszelką cenę, aby móc żyć. Osnowa mitu jest przecież dla żywych, a kto wie, może tylko umarli byliby zdolni poznać prawdę i wymierzyć sprawiedliwość (M, 94).

6 Postawę tę jednak należy docenić, ponieważ nawet u samego Jastruna nie jest oczywista. Swiadczy o tym wiersz Ifigenia $\mathrm{z}$ tomu Poezja $i$ prawda (1955). Utwór zawiera akceptację działań ofiarniczych, które chociaż okrutne są zarazem konieczne i uzasadnione. Jak bowiem komentował Stabryła: „Legenda o śmierci Ifigenii na ołtarzu Artemidy to dla poety symbol mądrości antycznych Greków, ich znajomości człowieka, rozumienia przez nich tragizmu ludzkiego losu" (S. Stabryła, Antyk $w$ poezji Mieczystawa Jastruna ( $w$ latach 1929-1959), „Eos” 1977, nr 2, s. 297; por. M. Jastrun, Poezje zebrane, Warszawa 1975, s. 395).

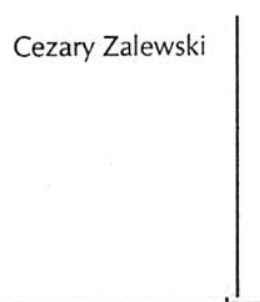


Przekształcenia mitów nie dokonują się zatem przypadkowo, ale są zamierzonym wysiłkiem mającym na celu eliminację opresji. Jeśli tragedia Ifigenii podlega minimalizacji, oznacza to, iż ci, którzy sporządzają tę redakcję, dokonują fałszerstwa: jeśli nie ma zbrodni, to nie ma też morderców. Jak słusznie podkreśla Jastrun, prawda o tym, co się wydarzyło, zostaje pogrzebana wraz $\mathrm{z}$ ofiarami.

Zamiar kłamliwego usprawiedliwienia zapewne by nie powstał, gdyby nie „narodziny nowej świadomości” (por. P, 108). Polegają one na zastąpieniu przemocy - współczuciem i litością, a jej pierwszymi przedstawicielkami są kobiety (Ifigenia, Antygona, Alkestis). W ten sposób postęp moralny uzyskuje dość dwuznaczny status: z jednej strony minimalizuje okrucieństwo, z drugiej - prowadzi do obłudnej cenzury, ukrywającej to, co faktycznie zaistniało.

Kwestia zmian jest też zasadnicza w Ofiarowaniu Ifigenii Herberta. Poeta, przedstawiając tytułowe wydarzenie, koncentruje się na momencie bezpośrednio poprzedzającym decydujący akt. Dlatego w utworze nie pojawi się ani problem rytualnego morderstwa, ani jego ewentualna ewolucja. Zasadnicze zagadnienie dotyczy bowiem selekcji, za pomocą której dokonana zostaje reprezentacja samej ofiary. Herbert koncentruje się wokół tego, w jaki sposób jeszcze żyjąca Ifigenia jest widziana przez uczestników obrzędu, a także przez odtwarzającą go sztukę.

Utwór prezentuje aż cztery perspektywy. Pierwsza, najważniejsza należy do głównego ofiarnika:

Agamemnon jest najbliżej stosu. Płaszcz zarzucił na głowę, ale oczu nie zamknął. Sądzi, że przez tkaninę dostrzeże błysk, który stopi jego córkę jak szpilkę do włosów ${ }^{7}$.

Etyczna dwuznaczność tego gestu istotnie wynika ze splotu wewnętrznie sprzecznych reakcji, których rozpoznanie nie jest jednak niemożliwe ${ }^{8}$. Agamemnon przypomina obłudnika, ponieważ, z jednej strony, naturalny odruch nie pozwala mu przyglądać się konaniu własnej córki, ale, z drugiej, koniecznie chce tę scenę zobaczyć. Współczucie nie jest bowiem w stanie przezwyciężyć religijnej potrzeby: ofiarowanie, sacri-ficalis, to przecież wykonanie sacrum, to działanie powodujące objawienie. Agamemnon nie chce widzieć tej śmierci, ale wie, że bez niej nie nastąpi oczekiwana teofania. Ukradkiem, w sposób zapewne niedoskonały podgląda więc ofiarę, dzięki której dostąpi wtajemniczenia.

7 Z. Herbert, Ofiarowanie Ifigenii, [w:] Hermes, pies i gwiazda, Wrocław 1997, s. 160.

8 Por. A. Kaliszewski, Gry Pana Cogito, Kraków 1982, s. 100; A. Fiut, Dwa spojrzenia na antyk: Kawafis i Herbert, [w:] Poznawanie Herberta 2, wybór i wstęp A. Franaszek, Kraków 2000, s. 292. 
Następnie Herbert prezentuje punkty widzenia Hipiasza i Kolchasa. Są one odmienne, ale zbliża je wyraźnie podkreślana deformacja, brak właściwego i precyzyjnego oglądu. Pod tym względem zbliżają się one do równie ograniczonego widoku, jaki jest udziałem Agamemnona. Powstaje więc sugestia, iż dla każdego z nich najważniejszy jest religijny wymiar wydarzenia, chociaż akcenty pozostają rozłożone inaczej. Jeśli bowiem perspektywa Agamemnona koncentruje się na ofiarniczej epifanii, to ci, którzy znajdują się dalej od ołtarza, obdarzeni zostają jej niepełnym, jednostronnym doświadczeniem. Hipiasz widzi jedynie - a redukcja ta ma charakter karykaturalny, jeśli nie monstrualny - zaciśnięte usta Ifigenii, ponieważ kojarzą się one $\mathrm{z}$ występkiem czy niewłaściwym zachowaniem ofiary. Kolchas natomiast dostrzega zarówno obiektywne (brak wiatru), jak i subiektywne (własna starość) „mankamenty”, które ofiara powinna usunąć. Dlatego to właśnie on daje znak do rozpoczęcia obrzędu.

$\mathrm{Z}$ tych trzech perspektyw Herbert konstruuje matrycę religijnego oglądu. Ofiara zawsze jest ambiwalentna: zła i dobra zarazem. Ifigenia uosabia naganne postępowanie, ale kiedy zostanie poświęcona, sprawi, że sami bogowie pokierują biegiem historii.

Ta właśnie perspektywa zostanie wyeliminowana, kiedy poeta przystąpi do rekonstrukcji wizji, jaką dysponuje najbardziej oddalony od ołtarza chór. Ofiarowanie traci w niej miejsce centralne i zostaje sprowadzone do jednego $\mathrm{z}$ wielu elementów obecnych na obrazie czy fresku. Niemniej, ten widok o, jak ironicznie zauważa poeta, właściwych proporcjach trafnie ilustruje funkcję obrzędu, chociaż - już nie sam obrzęd. To bowiem on, gromadząc wszystkich wokół siebie, daje początek i sens religii, władzy, armii, a nawet sztuce, która zajmuje się ich reprezentacją.

Powyższe zastawienie mitologicznych dyskursów skłania do dwóch zasadniczych wniosków. Pierwszy koncentruje się na statusie mitycznych morderstw, drugi natomiast - na perspektywie poznawczej, z jakiej są one ujmowane.

Jeśli bowiem spośród wielu analogicznych przykładów obaj pisarze wyraźną predylekcją obdarzają losy Minotaura oraz Ifigenii, oznacza to istnienie wyjątkowej specyfiki tych właśnie historii. Polega ona na tym, iż pozbawienie życia nie ma tu charakteru prywatnego, wynikłego np. z - tak preferowanego przez mity - konfliktu między wyłącznie dwoma antagonistami. Zbrodnia osadzona zostaje bowiem w szerszym kontekście, nawet jeśli jest on przywoływany aluzyjnie i niezbyt precyzyjnie. Zatem ów czyn to wynik pewnej interakcji, jaka pojawia się między jednostką a całym społeczeństwem, w obrębie któregc ona się znajduje. 
Mechanizm rządzący tą zbiorową egzekucją przedstawiany jest na dwa sposoby. Po pierwsze, Herbert - gdyż jego utwory są w tej kwestii zasadnicze - zakłada, iż stracenie Minotaura dokonane zostało w znacznym stopniu spontanicznie, impulsywnie, w sposób nie do końca przewidywalny. Natomiast zamordowanie Ifigenii ma schematyczny i skodyfikowany rytualnie przebieg. Zestawienie Historii Minotaura oraz Ofiarowania Ifigenii pokazuje jednak wyraźnie, iż oba akty zakładają tę samą zasadę odrzucenia: ten, kto zostanie zamordowany, podlega uprzedniej ekspulsji, wykluczeniu ze wspólnoty. Analogia ta nasuwa zresztą przypuszczenie - zapewne niedowodliwe, opierając się jedynie na powyższych utworach - zgodnie z którym między tym, co spontaniczne, a tym, co skodyfikowane, zachodziłaby relacja genetyczna. Nie jest bowiem wykluczone, iż rytualne morderstwo tylko powiela i odtwarza niespodziewaną eksplozję niegdysiejszej przemocy.

Po drugie $-\mathrm{z}$ faktu, iż dla obu pisarzy starożytna mitologia jest już obumarła (a nawet religijnie dysfunkcyjna), wynika możliwość zajęcia wobec niej różnych stanowisk. Przytoczone utwory pokazują, iż potrafią oni - w zależności od własnych strategii - dokonywać zarówno mitologizacji, jak też demitologizacji. Intrygująca jest przy tym zależność kierująca dystrybucją tych perspektyw: tam bowiem, gdzie pisarze decydują się na wierne odtworzenie mitycznych wyobrażen, tam ich narracja przyjmuje punkt widzenia społeczności przeprowadzającej egzekucję. I odwrotnie: tam, gdzie dominują zabiegi demitologizacyjne, tam wyeksponowana zostaje własna pozycja autora, która zresztą zbliża się do tej, jaką zajmuje bohater-ofiara.

Niewątpliwą stawką tych strategicznych roszad jest wgląd poznawczy. Pisarze, rekonstruując mityczną wizję dotyczącą Minotaura (Jastrun) czy Ifigenii (Herbert), dochodzą do wniosku, iż ów morderczy gest eliminacji potwora jest nie tylko uzasadniony, ale wręcz niezbędny. $\mathrm{Na}$ nim bowiem opiera się stabilizacja społeczna i władza; z niego rodzi się religia, historia czy sztuka. Można by nawet zaryzykować bardziej abstrakcyjne twierdzenie, zgodnie z którym eksponowane przez Herberta przeciwieństwo między ofiarą a zgromadzonymi wokół niej ofiarnikami jest źródłem i matrycą wszystkich opozycji, bez których nie dokonuje się żadne poznanie. Jak bowiem w Obecności mitu zauważył Leszek Kołakowski:

rozumieć cokolwiek potrafimy tylko ze względu na pary opozycyjne, których jakość rozumiana jest członem; [...] rozumiemy tylko przez kontrast, tylko wtedy, gdy umiemy zrozumieć to, co jest rozumiane nieobecnością, że przedmiot jawi się tylko na tle świata, którym nie jest ${ }^{9}$.

${ }^{9}$ L. Kołakowski, Obecność mitu, Warszawa 2005, s. 94. 
O tym, że dystynkcje wprowadzone przez rytuał są najbardziej fundamentalne, przekonuje możliwość redukcji ostatniego wyrażania: ofiara jawi się wyłącznie na tle grupy, do której już nie należy. Okazuje się, iż nawet logos filozofii - co zresztą wiemy dzięki Derridzie - nie jest uodporniony na zasadę ekspulsji.

Znamienny pozostaje jednak fakt, iż perspektywa demitologizacyjna powoduje - przynajmniej implicite - dekonstrukcję zarysowanej powyżej wizji. Istota tego procederu polega na podważeniu ofiarniczego, fundacyjnego gestu. Jeśli bowiem uzasadnienie mitologicznego morderstwa zostaje sprowadzone do gry nieistotnych pretekstów, wówczas okazuje się, iż składa się na nie wyłącznie okrutna, barbarzyńska siła. Tę diagnozę Herberta z Historii Minotaura Jastrun uzupełnia obserwacją o wstydliwym charakterze owej przemocy, której obraz podlega nieustannej modyfikacji. Wszystko po to, aby zapomnieć o tym, iż ofiara ani nie była niebezpiecznym potworem, ani nie popełniła karygodnych występków.

Zestawienie obu strategii prowadzi do nieuchronnej konkluzji o ich wzajemnej wyłączności. Zejście do sztolni mitów okazuje się zatem dwoiste i stawia nas, jak powiedziałby Herbert:

twarzą w twarz wobec okrutnej alternatywy - albo bezpieczeństwo, albo wolność.

Tertium non datur ${ }^{10}$.

${ }^{10}$ Z. Herbert, Securitas, [w:] Król mrówek, dz. cyt., s. 81 . 